\title{
Study of the effect of DNA polymorphisms in the mannose-binding lectin gene (MBL2) on disease severity in Slovak cystic fibrosis patients
}

\author{
Eva Tothova Tarova ${ }^{1}$, Helena Polakova ${ }^{2}$, Hana Kayserova ${ }^{3}$, Peter Celec ${ }^{1,4}$, Maria Zuzulova $^{5}$ \\ and Ludevit Kadasi ${ }^{1,2}$ \\ ${ }^{1}$ Department of Molecular Biology, Faculty of Natural Sciences, Comenius University Bratislava, Slovak Republic \\ ${ }^{2}$ Institute of Molecular Physiology and Genetics, Slovak Academy of Sciences, Bratislava, Slovak Republic \\ ${ }^{3}$ Cystic Fibrosis Centre, University Hospital with Policlinic, Bratislava, Slovak Republic \\ ${ }^{4}$ Institute of Pathophysiology, Faculty of Medicine, Comenius University Bratislava, Slovak Republic \\ ${ }^{5}$ Institute of Laboratory Medicine, St. Elisabeth Cancer Institute, Bratislava, Slovak Republic
}

\begin{abstract}
Lung infections are the leading cause of morbidity and mortality in cystic fibrosis (CF). Mannose-binding lectin (MBL) is a key factor in innate immunity. We therefore investigated whether MBL2 gene variants are associated with pulmonary function or susceptibility to Pseudomonas aeruginosa and Burkholderia cepacia infection in Slovak patients affected with CF. DNA polymorphisms in exon 1 and the promoter region were typed by single base primer extension assay in 91 patients and 100 healthy controls. The concentrations of MBL protein were determined in 34 patients by a sandwich enzyme-linked immunosorbent assay, and spirometric and microbiological data were collected from medical records. In this study we found that $M B L 2$ genotypes were associated neither with earlier acquisition of $P$. aeruginosa or B. cepacia nor with reduced pulmonary function among patients. Although MBL2 genotypes were associated with the MBL2 protein serum level, results were statistically significant only for polymorphisms in exon 1 , with $p=0.0008$. The role of the MBL2 gene in lung disease severity in CF patients represents a very complex phenomenon where both genetic and environmental factors play an important role in addition to that of the MBL2 gene. Understanding this complexity requires further studies based on a broader scale of genetic factors involving both a whole-genome approach and a larger patient cohort.
\end{abstract}

Key words: Cystic fibrosis - Mannose-binding lectin-polymorphism - Modifier gene - Lung function

Abbreviations: $\mathrm{CF}$, cystic fibrosis; $\mathrm{FEV}_{1}$, forced expiratory volume in 1 second; $\mathrm{MBL}$, mannosebinding lectin.

\section{Introduction}

Cystic fibrosis (CF) is the most common lethal inherited disease among Caucasians. The leading cause of mortality in $90 \%$ of CF patients is respiratory insufficiency due to chronic inflammation caused by bacterial colonization of the respiratory tract. The most important pathogens are Pseudomonas

Correspondence to: Eva Tothova Tarova, Department of Molecular Biology, Faculty of Natural Sciences, Comenius University Bratislava, Mlynska dolina B2-211, 84215 Bratislava, Slovak Republic E-mail: eva.tarova@gmail.com aeruginosa and Burkholderia cepacia (Carlsson et al. 2005). Pulmonary symptoms are highly variable among patients, and even among those in the same family.

It is assumed that the severity and progression of pulmonary dysfunction in CF is modulated by secondary genetic factors called CF modifiers (Cutting 2005; Knowles 2006). One of the first genes implicated as a pulmonary modifier in CF was the mannose-binding lectin 2 gene (MBL2) (Garred et al. 1999). MBL2 protein is an important mediator component of the innate immune defence system, which functions as an opsonin and complement activator. It is assigned to the family of proteins called collectins, because these contain 
collagen-like regions and lectin domains, and they bind to carbohydrate structures from a wide range of pathogenic bacteria, viruses, fungi and parasites through the lectin domain. MBL2 is synthesised in the liver by hepatocytes, secreted into the blood and circulates as dimers or hexamers composed of subunits containing three identical polypeptides (Petersen et al. 2001; Yarden et al. 2004).

The human MBL2 gene is derived from a single gene on chromosome 10q11.2-q21 (MBL1 is an inactive pseudogene) (Garred et al. 1999). It has been shown that MBL2 variant alleles causing low MBL2 serum levels are associated with an increased risk of different types of infections, primarily occurring in children (Summerfield et al. 1997), but also in adults (Summerfield et al. 1995).

The following three single nucleotide polymorphisms causing independently low serum levels of MBL2 are in exon 1 of the $M B L 2$ gene; allele $\mathrm{D}$ at codon 52 , allele $\mathrm{B}$ at codon 54 , and allele C at codon 57 (Madsen et al. 1994; Yarden et al. 2004; Dorfman et al. 2008). These amino acid changes are considered to affect the tertiary structure of the collagen region of the MBL2 protein. Heterozygosity or homozygosity for these polymorphisms result in little or no functional MBL2 protein, and hence these alleles have been named 0 (null) alleles, whereas the normal allele has been named A (Madsen et al. 1994; Garred et al. 1999; Yarden et al. 2004; Dorfman et al. 2008). Additionally, the $\mathrm{Y} / \mathrm{X}$ promoter polymorphism in codon -221 has a significant effect on the MBL2 serum level (Madsen et al. 1995; Garred et al. 1999; Yarden et al. 2004; Carlsson et al. 2005; Dorfman et al. 2008).

The aim of this research is to study the presence of structural MBL2 variant alleles and the promoter variant, with respect to MBL2 protein level and consequent influences on development of pulmonary disease in Slovak CF patients.

\section{Materials and Methods}

In this study, 91 Slovak CF patients and 100 randomly selected healthy people were included. Clinical diagnosis of $\mathrm{CF}$ was performed at the Centre of Cystic Fibrosis (University Hospital with Policlinic, Bratislava) and departments of clinical and medical genetics in Slovakia.

Of the 91 patients, 68 were homozygous for the p.F508del mutation, while 23 patients were compound heterozygous for the mutation p.F508del with these other severe mutations: g.CFTRdele2,3 (5), p.G542X (5), p.N1303K (3), g.2184insA (2), p.R553X (2), g.3659delC (1), g.1898+1G>A (1), p.W1282X (1), g.605insT (1), g.4108delT (1), p.E831X+p.R851X (1).

The median diagnostic age of patients aged between 1 month and 19 years was 20.7 months while the median age of patients from 1.2 to 40.0 years at the time of $M B L 2$ gene variant genotyping was 13.8 years. The patient group consisted of 47 females and 44 males.
The $\mathrm{FEV}_{1}(\%)$ value, signifying the forced expiratory volume in 1 second, was chosen to measure lung function (Aurora et al. 2000). $\mathrm{FEV}_{1}$ predicted values were calculated according to the Knudson coefficient (Knudson et al. 1983) and were measurable in 73 patients. Spirometer measurements were not performed on patients under 6 years of age.

Chronic bacterial infections with Pseudomonas aeruginosa were recorded in 65 patients and with Burkholderia cepacia in 26 patients.

DNA samples were isolated using the Puregen ${ }^{\mathrm{TM}}$ DNA purification kit (Qiagen, Germany) and the SNaPshot method in multiplexed PCR reaction, also referred to as "minisequencing", was employed in MBL2 gene polymorphism analysis (Quintáns et al. 2004; Yarden et al. 2004). Yarden et al's method was modified in the following steps:

1) Amplification of target genomic DNA sequence by PCR. The PCR reaction was performed in a volume of $25 \mu \mathrm{l} \mathrm{con-}$ taining $1 \times$ buffer $\left(0.1 \mathrm{~mol} / 1\right.$ Tris- $\mathrm{HCl}, 0.015 \mathrm{~mol} / 1 \mathrm{MgCl}_{2}$, $0.5 \mathrm{~mol} / \mathrm{l} \mathrm{KCl}, 1.7 \mathrm{~g} / \mathrm{l} \mathrm{BSA}, 1 \%$ Triton X-100), $0.2 \mathrm{mmol} / \mathrm{l}$ dNTP (Invitrogen, USA), $2 \mathrm{mmol} / \mathrm{l} \mathrm{MgCl}_{2}$ (Invitrogen, USA), $1 \mathrm{U} / \mu \mathrm{l}$ Taq DNA polymerase (Invitrogen, USA), $0.4 \mu \mathrm{mol} / \mathrm{l}$ primers (Sigma, Germany) (Table 1) and 200 $\mathrm{ng} / \mu \mathrm{l}$ DNA. The mixture was then incubated in an XPThermal Cycler (Bioer Technology Co., China) using the following amplification profile: denaturation at $94^{\circ} \mathrm{C}$ for $4 \mathrm{~min}, 32$ cycles at $94^{\circ} \mathrm{C}$ for $1 \mathrm{~min}, 62^{\circ} \mathrm{C}$ for $40 \mathrm{~s}, 72^{\circ} \mathrm{C}$ for $2 \mathrm{~min}$, and a final extension step at $72^{\circ} \mathrm{C}$ for $7 \mathrm{~min}$. The length of PCR product was $782 \mathrm{bp}$ which was verified by gel electrophoresis on $1.5 \%$ agarose gel.

2) Purification of PCR product before extension reaction by Exonuclease I/Shrimp alkaline phosphatase (USB, USA).

3) $\mathrm{SNaPshot}$ extension reaction by $\mathrm{SNaPshot}{ }^{\mathrm{TM}}$ (Applied Biosystems, USA) SNP detection kit and 4 unlabelled single nucleotide extension primers (Sigma, Germany) for MBL2 SNPs (Table 1).

4) Purification of PCR product following the extension reaction was conducted with Shrimp alkaline phosphatase (Fermentas, USA).

5) The mixture for capillary gel electrophoresis contained $9.15 \mu \mathrm{Hi}-\mathrm{Di}^{\mathrm{TM}}$ formamide (Applied Biosystems, USA), $0.25 \mu \mathrm{l}$ GeneScan ${ }^{\mathrm{TM}} 120 \mathrm{LIZ}^{\mathrm{TM}}$ size standard (Applied Biosystems, USA) and $0.6 \mu \mathrm{l} \mathrm{SNaPshot} \mathrm{product.} \mathrm{After}$ denaturation, the mixture was resolved on an ABI PRISM 3100 Avant genetic analyzer (Applied Biosystems, USA).

\section{Statistical analysis}

For analysis and date evaluation the GeneMapper v3.7 software was used. One-way ANOVA with an LSD post-hoc test was performed for statistical analysis of quantitative parameters, plus the Chi-squared test for testing associations between quantitative parameters. $p$-values less than 0.05 were considered significant. Data was analyzed using XLStatistics 
Table 1. Sequences of primers for amplification of the $M B L 2$ gene fragment and sequences of single nucleotide extension primers for MBL2 SNPs

\begin{tabular}{ll}
\hline Primer & Nucleotide sequence 5' $\rightarrow 3^{\prime}$ \\
\hline YX-F & 5'-CCTTCCTCTTTGGATCACCA-3' \\
YX-R & 5'-CAGGCAGTTTCCTCTGGAAG-3' \\
AB $(875 \mathrm{~g} / \mathrm{a})$ & 5'-CGGCTTCCCAGGCAAAGATGGGCGTGATG-3' \\
AC $(884 \mathrm{~g} / \mathrm{a}) \mathrm{R}$ & 5'-AAAAAAAAAAAAAAAACCTGGTTCCCCCTTTTCT-3' \\
AD $(868 \mathrm{c} / \mathrm{t})$ & 5'-AAAAAAAAAAAAAGCATCAACGGCTTCCCAGGCAAAGATGGG-3' \\
YX $(425 \mathrm{~g} / \mathrm{c})$ & 5'-AAAAAAAAAAAAAAAAAAACAATGCAGGGTCCCATTTGTTCTACTCGGAC-3' \\
\hline
\end{tabular}

Primers were modified from the original protocol Yarden et al. (2004). The concentration of YX-F and YX-R primers was $0.4 \mu \mathrm{mol} / \mathrm{l}$, and of other 4 SNP primers $0.2 \mu \mathrm{mol} / \mathrm{l}$. The anneling temperature of first two primers was $62^{\circ} \mathrm{C}$ and the lenght of PCR product $782 \mathrm{bp}$. F, forward primer; R, reverse primer.

5.0 and Microsoft Excel 2007 and are presented as mean (or \pm the standard deviation).

Genotypes were verified by direct sequencing using the BigDye Terminator v1.1 cycle sequencing kit (Applied Biosystems, USA).

Concentrations of MBL2 protein were determined in 34 patients by a Sandwich enzyme-linked immunosorbent assay (ELISA) on microtitre plates coated with monoclonal anti-MBL antibodies.

\section{Results}

\section{MBL2 gene variants and genotypes}

Genotyping was performed separately for the exon 1 variants and the promoter polymorphism. In exon 1 variants, the AA genotype represents patients with only wild-type variants, genotypes $\mathrm{AB}, \mathrm{AC}$ and $\mathrm{AD}$ were commonly designed as $\mathrm{A} 0$, where $A$ represents the wild-type allele with 0 for alleles $B, C$ or $\mathrm{D}$, and the 00 genotype specified compound heterozygotes for non-wild-type alleles (BC, BD, CD) or homozygotes for the non-wild-type alleles (BB, CC, DD). The only homozygote for the $\mathrm{BB}$ polymorphism was detected in one control subject. Polymorphism in the promoter region was classified as follows: YY were homozygotes for wild-type allele, YX heterozygotes and XX homozygotes for non-wild-type allele (Table 2).

Comparison of genotype frequencies between patients and controls showed no significant differences for the exon 1 variants $(p=0.438)$ or for the promoter polymorphism ( $p=0.666$, Table 2$)$. Likewise, combining these polymorphisms into joined genotypes (AA-YY, AA-YX, AA-XX, A0YY, A0-YX, 00-YY, 00-YX) did not show significant differences between patients and controls ( $p=0.744$, Table 3 ).

\section{Spirometric data and MBL2 gene variants}

The $\mathrm{FEV}_{1}$ value efficiently correlates with lung disease prognosis in CF (Aurora et al. 2000). The average age of patients at spirometric measurement was 14 years, and the average $\mathrm{FEV}_{1}$ value was $77.9 \%$ ( $\pm 22.44 \%)$. The $\mathrm{FEV}_{1}$ values were evaluated as follows: 1) $\geq 80 \%$ normal value, 2) 60-79\% mild type, 3) 45-59\% moderate severe type, 4$)<45 \%$ severe type. Although, we found more AA patients with $\mathrm{FEV}_{1}$ above $80 \%$ than $\mathrm{A} 0$ and 00 patients, these results were not statistically significant $(p=0.802$, Table 4). For the promoter polymorphism, we observed no differences between lung function and Y genotypes (Table 4).

In the next step, the patients were subdivided into groups, according to the level of MBL2: 1) high producers, genotypes AA-YY and AA-YX $(\geq 1000 \mu \mathrm{g} / \mathrm{l})$, and 2) low producers, genotypes AA-XX, A0-YY, A0-YX, 00-YY, and 00-YX $(<1000$ $\mu \mathrm{g} / \mathrm{l}$ ) (Yarden et al. 2004). The results were similar to those for polymorphisms in exon 1, where more patients were found with $\mathrm{FEV}_{1}$ above $80 \%$ in the group of high producers than in low producers, but neither of these results was statistically significant ( $p=0.18$, Table 4$)$.

Analysis of other spirometric data evaluated in this study besides FVC (forced vital capacity), such as PEF (peak

Table 2. Genotype frequencies of MBL2 gene variants in Slovak patients with $\mathrm{CF}$ and controls

\begin{tabular}{llcccc}
\hline \multirow{2}{*}{ Genotypes } & \multirow{2}{*}{ Polymorphisms } & \multicolumn{2}{c}{ CF patients } & \multicolumn{2}{c}{ Controls } \\
& & $\mathrm{n}$ & $(\%)$ & $\mathrm{n}$ & $(\%)$ \\
\hline $\mathrm{AA}$ & & 58 & 63.7 & 66 & 66 \\
\hline \multirow{3}{*}{$\mathrm{A} 0$} & $\mathrm{AB}$ & 17 & 18.7 & 18 & 18 \\
& $\mathrm{AC}$ & 4 & 4.4 & 5 & 5 \\
& $\mathrm{AD}$ & 7 & 7.7 & 9 & 9 \\
\hline \multirow{3}{*}{00} & $\mathrm{BB}$ & 0 & - & 1 & 1 \\
& $\mathrm{BC}$ & 1 & 1.1 & 0 & - \\
& $\mathrm{BD}$ & 2 & 2.2 & 1 & 1 \\
\hline YY & $\mathrm{CD}$ & 2 & 2.2 & 0 & - \\
\hline YX & & 62 & 68.1 & 62 & 62 \\
\hline XX & & 27 & 29.7 & 34 & 34 \\
\hline Total & & 2 & 2.2 & 4 & 4 \\
\hline
\end{tabular}

Exon 1: $p=0.438$; promoter: $p=0.666$. 
Table 3. Genotype frequencies of all 4 polymorphisms in CF patients and controls

\begin{tabular}{lcccc}
\hline Genotypes & \multicolumn{2}{c}{ CF patients } & \multicolumn{2}{c}{ Controls } \\
& $\mathrm{n}$ & $(\%)$ & $\mathrm{n}$ & $(\%)$ \\
\hline AA-YY & 36 & 39.5 & 34 & 34 \\
AA-YX & 20 & 22 & 29 & 29 \\
AA-XX & 2 & 2.2 & 3 & 3 \\
A0-YY & 22 & 24.2 & 26 & 26 \\
A0-YX & 6 & 6.6 & 6 & 6 \\
00-YY & 4 & 4.4 & 2 & 2 \\
00-YX & 1 & 1.1 & 0 & - \\
Total & 91 & 100 & 100 & 100 \\
\hline
\end{tabular}

$p=0.744$

expiratory flow rate) and MEF (maximum expiratory flow rate), showed no significant association with particular MBL2 genotypes, therefore the results of these statistical analyses are not presented. Similarly, the association analysis of $\mathrm{Cl}^{-2}$ ion concentration with $M B L 2$ genotypes exhibited no statistically significant results.

\section{MBL2 protein level}

Data on the MBL2 serum level was available in $34 \mathrm{CF}$ patients (Table 5). The average value was $1967.5 \mu \mathrm{g} / \mathrm{l}$, with a median of $1363.2 \mu \mathrm{g} / \mathrm{l}$. Our results show that high levels of MBL2 $(\geq 1000 \mu \mathrm{g} / \mathrm{l})$ are associated with genotype AA and low levels $(<1000 \mu \mathrm{g} / \mathrm{l})$ with genotypes A0. These results are statistically significant $(p=0.0008)$. The average value of MBL2 in patients with AA the genotype was $2734.12 \mu \mathrm{g} / \mathrm{l}$ (median $1901.6 \mu \mathrm{g} / \mathrm{l}$ ), while in patients with genotype A0 it was $364.7 \mu \mathrm{g} / \mathrm{l}$ (median $89.0 \mu \mathrm{g} / \mathrm{l})(p=0.0008)$. Protein levels were also compared with the promoter polymorphism and these results were, also statistically insignificant (YY had an average value of $2075.94 \mu \mathrm{g} / \mathrm{l}$ with median $1691.5 \mu \mathrm{g} / \mathrm{l}$ and $\mathrm{YX}$ had $1740.9 \mu \mathrm{g} / \mathrm{l}$ with a median of $1270.6 \mu \mathrm{g} / \mathrm{l})(p=0.14)$.

\section{MBL2 genotypes and bacterial infection}

The majority of the patients (71.4\%) had experienced positive cultures for $P$. aeruginosa. No significant correlation was found between genotypes and the age of onset of the first $P$. aeruginosa infection, and on average, patients with AA, $\mathrm{A} 0$, and 00 genotypes were infected at about 10 years of age. Significant differences were, however, found in MBL2 levels in infected patients with $P$. aeruginosa. Patients with the AA genotype had protein levels of $2764.29 \mu \mathrm{g} / \mathrm{l}$ (median $1901.6 \mu \mathrm{g} / \mathrm{l})$, while patients with A0 and 00 genotype had only $371.4 \mu \mathrm{g} / \mathrm{l}$ (median $89.0 \mu \mathrm{g} / \mathrm{l})(p=0.0008)$.

Similar results were observed for $B$. cepacia infection. Patients with the AA genotype had a protein level of $1712.87 \mu \mathrm{g} / \mathrm{l}$ (median $1271.8 \mu \mathrm{g} / \mathrm{l}$ ) while A0 patients had a significantly lower level at $233.6 \mu \mathrm{g} / \mathrm{l}$ (median $27.7 \mu \mathrm{g} / \mathrm{l})(p=0.001)$.

In this study we also assessed the correlation of analyzed DNA polymorphisms with other clinical symptoms such as aspergillosis, increased immunoglobulin levels, hepatopathy, pancreatic insufficiency, meconium ileus, hypo-albuminaemia, cystic fibrosis related diabetes mellitus, atopy, body mass index, cardiomyopathy, pneumothorax, and nasal polyps. As these results did not show any statistical significance, they are not presented herein.

\section{Discussion}

Lung disease, the major life-limiting complication of CF, is poorly correlated with types of mutations in the diseasecausing CFTR gene. Emerging data suggests a multi-factorial modulation of lung disease severity including genetic, environmental, and stochastic factors (Cutting 2005). In recent years, many genes have been studied as candidate modifier genes in CF. One of the first of these was the MBL2 gene, an important mediator component of the innate defence system. Variants in the MBL2 gene showed an association with multiple symptoms of CF in some studies but not in others (McDougal et al. 2010).

No significant differences in the frequencies of genotypes in the $M B L 2$ gene were found in our study, and similar results have been collaborated in other works (Garred et al. 1999; Yarden et al. 2004; Dorfman et al. 2008; Faria et al. 2009).

Although the majority of candidate gene studies have documented worse lung disease with insufficient MBL2 genotypes (Garred et al. 1999; Yarden et al. 2004; Dorfman

Table 4. Distribution of $M B L 2$ genotypes according to $\mathrm{FEV}_{1}$ in CF patients $(n=73)$

\begin{tabular}{|c|c|c|c|c|c|c|c|}
\hline & & $\mathrm{AA}(\%)$ & $\mathrm{A} 0,00(\%)$ & YY & $\mathrm{YX}, \mathrm{XX}$ & High & Low \\
\hline \multirow{4}{*}{$\mathrm{FEV}_{1}(\%)$} & $\geq 80$ & $27(55.1)$ & $9(37.5)$ & $23(48.94)$ & $13(50)$ & $27(57.45)$ & $9(34.62)$ \\
\hline & $60-79$ & $11(22.45)$ & $9(37.5)$ & $14(29.78)$ & $6(23.08)$ & $10(21.28)$ & $10(38.46)$ \\
\hline & $45-59$ & $8(16.33)$ & $2(8.33)$ & $5(10.64)$ & $5(19.23)$ & 7 (14.89) & $3(11.54)$ \\
\hline & $\leq 45$ & $3(6.12)$ & $4(16.67)$ & $5(10.64)$ & $2(7.69)$ & $3(6.38)$ & $4(15.38)$ \\
\hline $\mathrm{n}$ & & 49 & 24 & 47 & 26 & 47 & 26 \\
\hline
\end{tabular}

High producers are AA-YY, AA-YX; low producers are AA-XX, A0-YY, A0-YX, 00-YY, 00-YX ( $p=0.18)$. 
Table 5. MBL2 protein level in CF patients $(n=34)$

\begin{tabular}{lcccc}
\hline \multirow{2}{*}{ MBL2 $(\mu \mathrm{g} / \mathrm{l})$} & \multicolumn{4}{c}{ Genotypes } \\
& AA-YY & AA-YX & A0-YY & A0-YX \\
\hline$\leq 100$ & 1 & 1 & 3 & 3 \\
$100-1000$ & 1 & 0 & 3 & 1 \\
$\geq 1000$ & 14 & 6 & 1 & 0 \\
\hline
\end{tabular}

Grey color in table indicates the number of patients deviating from the expected value. AA genotype should be associated with higher values, while $\mathrm{A} 0$ genotype with lower values. $p=0.0008$.

et al. 2008; Chalmers et al. 2011), a few studies showed no effect (Carlsson et al. 2005; Collaco and Cutting 2008), while Collaco and Cutting (2008) reported reduced lung function with high or intermediate producers.

MBL2 deficiency has been associated with a more rapid decline in pulmonary function (Dorfman et al. 2008), and, although some association was observed in our cohort between genotypes in MBL2 gene and spirometric data, these results were not statistically significant. Spirometric data is not always reliable, and it can vary with age, sex and environmental factors. Other airway symptoms, such as sinusitis and nasal polyps have also been reported to affect lung function (Carlsson et al. 2005).

The $\mathrm{A} 0$ and $00 \mathrm{MBL} 2$ genotypes are known to result in low MBL protein level (Muhlebach et al. 2006), and this was also confirmed in our results. This is in contrast to the promoter polymorphism which does not affect the protein level. This observation can be explained by the fact that homozygosity for any of the structural mutations or their compound heterozygozity prevents oligomerization of MBL2, while homozygosity for the $\mathrm{X}$ allele reduces production of the MBL2 oligomer (Dorfman et al. 2008). Disease association studies involving MBL have often been conducted at the genotype level instead of measuring the MBL protein concentration, but ideally, both genotype and protein data should be analyzed (Muhlebach et al. 2006). In our group of 23 patients with AA genotype, only 3 had a lower protein level than $1000 \mathrm{ng} / \mathrm{ml}$, and in $11 \mathrm{~A} 0$ patients only 1 had a protein level higher than $1000 \mathrm{ng} / \mathrm{ml}$ (Table 5). These results indicate an association between genotypes and protein levels. Results of the MBL protein level average values corresponded with polymorphisms in exon 1 .

In some studies, analysis of the age of contraction of first infection with Pseudomonas aeruginos showed that MBL2 deficiency was significantly associated with earlier onset of infection (Summerfield et al. 1995, 1997; Dorfman et al. 2008; Chalmers et al. 2011). However, other studies have substantiated our results that there is no effect of MBL2 variation on colonization or on the age of acquisition (Garred et al. 1999; Yarden et al. 2004; Collaco et al. 2008).
McDougal et al. (2010) found that MBL2 genotypes corresponding to low levels of MBL2 were associated with earlier $P$. aeruginosa infection than the genotypes which corresponded to high levels of MBL. In our cohort, A0 patients with bacterial infection had a lower protein level than AA patients, but clinical symptoms and pulmonary function did not reflect these findings. This may be explained by the fact that the MBL protein is synthesized exclusively in the liver and therefore does not provide a protective role against $P$. aeruginosa colonization, since the MBL protein reaches the inflammation site quite late (Ezekowitz et al. 1988).

In conclusion, varying results achieved so far in the study of the relationship of the $M B L 2$ gene to lung disease severity in CF patients indicate that this represents a very complex phenomenon. Besides the MBL2 gene itself, other factors, both genetic and environmental, play an important role. Understanding this complexity requires further studies based on a broader scale of genetic factors, with the whole-genome approach and a more extensive cohort of patients.

Acknowledgements. This contribution is the result of the project implementation "Diagnostics of socially important disorders in Slovakia, based on modern biotechnologies" ITMS 26240220058, supported by the Research \& Developmental Operational Programme funded by the ERDF. Furthermore, we thank Ray Marshall for English revision and helpful comments on the manuscript.

\section{References}

Aurora P., Wade A., Whitmore P., Whitehead B. (2000): A model for predicting life expectancy of children with cystic fibrosis. Eur. Respir. J. 16, 1056-1060 http://dx.doi.org/10.1034/j.1399-3003.2000.16f06.x

Carlsson M., Sjöholm A. G., Eriksson L., Thiel S., Jensenius J. C., Segelmark M., Truedsson L. (2005): Deficiency of the mannan-binding lectin pathway of complement and poor outcome in cystic fibrosis: bacterial colonization may be decisive for a relationship. Clin. Exp. Immunol. 139, 306-313 http://dx.doi.org/10.1111/j.1365-2249.2004.02690.x

Chalmers J. D., Fleming G. B., Hill A. T., Kilpatrick D. C. (2011): Impact of mannose-binding lectin insufficiency on the course of cystic fibrosis: A review and meta-analysis. Glycobiology 21, 271-282 http://dx.doi.org/10.1093/glycob/cwq161

Collaco J. M., Cutting G. R. (2008): Update on gene modifiers in cystic fibrosis. Curr. Opin. Pulm. Med. 14, 559-566 http://dx.doi.org/10.1097/MCP.0b013e3283121cdc

Cutting G. R. (2005): Modifier genetics: cystic fibrosis. Annu. Rev. Genomics. Hum. Genet. 6, 237-260 http://dx.doi.org/10.1146/annurev.genom.6.080604.162254 Dorfman R., Sandford A., Taylor C., Huang B., Frangolias D., Wang Y., Sang R., Pereira L., Sun L., Berthiaume Y., Tsui L. C., Paré P. D., Durie P., Corey M., Zielenski J. (2008): Complex two-gene modulation of lung disease severity in children with cystic fibrosis. J. Clin. Invest. 118, 1040-1049 
Ezekowitz R. A., Day L. E., Herman G. A. (1988): A human mannose-binding protein is an acute-phase reactant that shares sequence homology with other vertebrate lectins. J. Exp. Med. 167, 1034-1046 http://dx.doi.org/10.1084/jem.167.3.1034

Faria E. J., Faria I. C., Ribeiro J. D., Ribeiro A. F., Hessel G., Bertuzzo C. S. (2009): Association of MBL2, TGF- $\beta 1$ and CD14 gene polymorphisms with lung disease severity in cystic fibrosis. J. Bras. Pneumol. 35, 334-342 http://dx.doi.org/10.1590/S1806-37132009000400007

Garred P., Pressler T., Madsen H. O., Frederiksen B., Svejgaard A., Hoiby N., Schwartz M., Koch C. (1999): Association of mannose-binding lectin gene heterogeneity with severity of lung disease and survival in cystic fibrosis. J. Clin. Invest. 104, 431-437 http://dx.doi.org/10.1172/JCI6861

Knowles M. R. (2006): Gene modifiers of lung disease. Curr. Opin. Pulm. Med. 12, 416-421 http://dx.doi.org/10.1097/01.mcp.0000245707.59138.40

Knudson R. J., Lebowitz M. D., Holberg C. J., Burrows B. (1983): Changes in the normal maximal expiratory flow-volume curve with growth and aging. Am. Rev. Respir. Dis. 127, 725-734

Madsen H. O., Garred P., Kurtzhals J. A., Lamm L. U., Ryder L. P., Thiel S., Svejgaard A. (1994): A new frequent allele is the missing link in the structural polymorphism of the human mannan-binding protein. Immunogenetics 40, 37-44 http://dx.doi.org/10.1007/BF00163962

Madsen H. O., Garred P., Thiel S., Kurtzhals J. A., Lamm L. U., Ryder L. P., Svejgaard A. (1995): Interplay between promoter and structural gene variants control basal serum level of mannan-binding protein. J. Immunol. 155, 3013-3020

McDougal K. E., Green D. M., Vanscoy L. L., Fallin M. D., Grow M., Cheng S., Blackman S. M., Collaco J. M., Henderson L. B., Naughton K., Cutting G. R. (2010): Use of a modeling framework to evaluate the effect of a modifier gene
(MBL2) on variation in cystic fibrosis. Eur. J. Hum. Genet. 18, 680-684 http://dx.doi.org/10.1038/ejhg.2009.226

Muhlebach M. S., MacDonald S. L., Button B., Hubbard J. J., Turner M. L., Boucher R. C., Kilpatrick D. C. (2006): Association between mannan-binding lectin and impaired lung function in cystic fibrosis may be age-dependent. Clin. Exp. Immunol. 145, 302-307 http://dx.doi.org/10.1111/j.1365-2249.2006.03151.x

Petersen S. V., Thiel S., Jensenius J. C. (2001): The mannan-binding lectin pathway of complement activation: biology and disease association. Mol. Immunol. 38, 133-149 http://dx.doi.org/10.1016/S0161-5890(01)00038-4

Quintáns B., Alvarez-Iglesias V., Salas A., Phillips C., Lareu M. V., Carracedo A. (2004): Typing of mitochondrial DNA coding region SNPs of forensic and anthropological interest using SNaPshot minisequencing. Forensic. Sci. Int. 140, 251-257 http://dx.doi.org/10.1016/j.forsciint.2003.12.005

Summerfield J. A., Ryder S., Sumiya M., Thursz M., Gorchein A., Monteil M. A., Turner M. W. (1995): Mannose binding protein gene mutations associated with unusual and severe infections in adults. Lancet 345, 886-889 http://dx.doi.org/10.1016/S0140-6736(95)90009-8

Summerfield J. A., Sumiya M., Levin M., Turner M. W. (1997): Association of mutations in mannose binding protein gene with childhood infection in consecutive hospital series. BMJ 314, 1229-1232

Yarden J., Radojkovic D., De Boeck K., Macek M. Jr., Zemkova D., Vavrova V., Vlietinck R., Cassiman J. J., Cuppens H. (2004): Polymorphisms in the mannose binding lectin gene affect the cystic fibrosis pulmonary phenotype. J. Med. Genet. 41, 629-633 http://dx.doi.org/10.1136/jmg.2003.017947

Received: September 5, 2011

Final version accepted: September 29, 2011 